\title{
From laboratory manipulations to Earth system models: scaling calcification impacts of ocean acidification
}

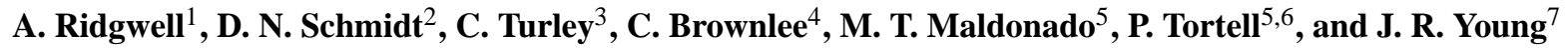 \\ ${ }^{1}$ School of Geographical Sciences, University of Bristol, UK \\ ${ }^{2}$ Department of Earth Sciences, University of Bristol, UK \\ ${ }^{3}$ Plymouth Marine Laboratory, Plymouth, UK \\ ${ }^{4}$ Marine Biological Association, Citadel Hill, Plymouth, UK \\ ${ }^{5}$ Department of Earth and Ocean Sciences, University of British Columbia, Vancouver, Canada \\ ${ }^{6}$ Department of Botany, University of British Columbia, Vancouver, Canada \\ ${ }^{7}$ Palaeontology Department, The Natural History Museum, London, UK
}

Received: 24 March 2009 - Published in Biogeosciences Discuss.: 1 April 2009

Revised: 4 November 2009 - Accepted: 10 November 2009 - Published: 23 November 2009

\begin{abstract}
The observed variation in the calcification responses of coccolithophores to changes in carbonate chemistry paints a highly incoherent picture, particularly for the most commonly cultured "species", Emiliania huxleyi. The disparity between magnitude and potentially even sign of the calcification change under simulated end-of-century ocean surface chemical changes (higher $p \mathrm{CO}_{2}$, lower $\mathrm{pH}$ and carbonate saturation), raises challenges to quantifying future carbon cycle impacts and feedbacks because it introduces significant uncertainty in parameterizations used for global models. Here we compile the results of coccolithophore carbonate chemistry manipulation experiments and review how ocean carbon cycle models have attempted to bridge the gap from experiments to global impacts. Although we can rule out methodological differences in how carbonate chemistry is altered as introducing an experimental bias, the absence of a consistent calcification response implies that model parameterizations based on small and differing subsets of experimental observations will lead to varying estimates for the global carbon cycle impacts of ocean acidification. We highlight two pertinent observations that might help: (1) the degree of coccolith calcification varies substantially, both between species and within species across different genotypes, and (2) the calcification response across mesocosm and shipboard incubations has so-far been found to be relatively consistent. By analogy to descriptions of plankton growth rate vs. temperature, such as the "Eppley curve",
\end{abstract}

Correspondence to: A. Ridgwell (andy@seao2.org) which seek to encapsulate the net community response via progressive assemblage change rather than the response of any single species, we posit that progressive future ocean acidification may drive a transition in dominance from more to less heavily calcified coccolithophores. Assemblage shift may be more important to integrated community calcification response than species-specific response, highlighting the importance of whole community manipulation experiments to models in the absence of a complete physiological understanding of the underlying calcification process. However, on a century time-scale, regardless of the parameterization adopted, the atmospheric $p \mathrm{CO}_{2}$ impact of ocean acidification is minor compared to other global carbon cycle feedbacks.

\section{Introduction}

Oceans act as an important carbon sink, absorbing nearly half of the $\mathrm{CO}_{2}$ released into the atmosphere since the industrial revolution $(118 \mathrm{PgC})$ through the burning of fossil fuels and cement manufacture (or roughly a third, if $\mathrm{CO}_{2}$ emissions from land use and deforestation are also included) (Sabine et al., 2004). Although increased ocean uptake of $\mathrm{CO}_{2}$ has therefore limited the current extent of climate change by reducing the atmospheric $\mathrm{CO}_{2}$ concentration that would have been reached in the absence of the ocean $\mathrm{CO}_{2}$ sink, this comes at a price. On a century time-scale, the net effect of dissolving $\mathrm{CO}_{2}$ in seawater can be written: $\mathrm{CO}_{2}+\mathrm{H}_{2} \mathrm{O}+\mathrm{CO}_{3}^{2-} \rightarrow 2 \mathrm{HCO}_{3}^{-}$with some of the bicarbonate ions $\left(\mathrm{HCO}_{3}^{-}\right)$undergoing dissociation to release hydrogen ions (Zeebe and Wolf-Gladrow, 2001) and causing

Published by Copernicus Publications on behalf of the European Geosciences Union. 
"ocean acidification" (Caldeira and Wickett, 2003). The consequence of lowering the concentration of carbonate ions $\left(\mathrm{CO}_{3}^{2-}\right)$ in ocean waters is that the saturation state of the mineral calcium carbonate $\left(\mathrm{CaCO}_{3}\right)$, defined:

$\Omega=\frac{\left[\mathrm{Ca}^{2+}\right] \cdot\left[\mathrm{CO}_{3}^{2-}\right]}{K_{s p}}$

(where $K_{s p}$ is a solubility constant) is reduced. This is important because the lower the saturation state, the thermodynamically less favorable it is for calcification to take place, and for $\Omega<1.0, \mathrm{CaCO}_{3}$ will tend to dissolve. The strong coupling between increasing $p \mathrm{CO}_{2}$, and decreasing $\mathrm{pH}$ and $\Omega$ holds for societally relevant (order 100-1000 year) timescales. (We will often adopt the short-hand of " $\mathrm{CO}_{2}$ " in this manuscript when we mean the full range of coupled aqueous carbonate chemistry changes). Beyond a few millennia, buffering of ocean chemistry by dissolution of carbonates in deep-sea sediments and rock weathering on land progressively alters the relationship between these three parameters and ultimately, on million year time-scales and beyond, $\mathrm{pH}$ and $\Omega$ are effectively decoupled (Ridgwell, 2005).

Concerns were raised in the late 1990s that reductions in surface ocean $\mathrm{pH}, \mathrm{CO}_{3}^{2-}$, and carbonate saturation resulting from the uptake of fossil fuel $\mathrm{CO}_{2}$ from the atmosphere might adversely affect the ability of marine plankton such as coccolithophorids and foraminifera to produce calcium carbonate shells (Wolf-Gladrow et al., 1999). The wide availability of physiologically well characterized strains of calcifying phytoplankton in long-term culture enabled the impact of ocean acidification to be tested. Early laboratory experiments carried out on the most abundant modern species of coccolithophorid, Emiliania huxleyi, in which the $\mathrm{pH}$ of the growth medium was decreased by addition of acid, produced varying calcification responses (Buitenhuis et al., 1999; Nimer and Merrett, 1993). However, the chemical conditions used in these manipulations often deviated substantially from either modern or possible future geochemistry. Subsequent laboratory experiments using E. huxleyi manipulated $\mathrm{pH}$ to simulate a more "realistic" range of glacial and future $\mathrm{CO}_{2}$ changes, and showed a clear overall decrease in carbonate production across low $\mathrm{pH}$ treatments compared to the control (i.e., current ocean $\mathrm{pH}$ ) together with the occurrence of malformed liths (calcium carbonate plates) (Riebesell et al., 2000; Zondervan et al., 2001). This result was consistent with contemporary ship-board experiments in the NE Pacific conducted with either acid/base additions or $\mathrm{CO}_{2}$ bubbling and which also showed a clear decrease in calcification at elevated $\mathrm{CO}_{2}$ (Riebesell et al., 2000).

More recent experiments carried out on E. huxleyi, both in the laboratory (Feng et al., 2008; Sciandra et al., 2003) and in mesocosms (Delille et al., 2005; Engel et al., 2005) generally supported a strong and detrimental impact of ocean acidification on phytoplankton calcification. Studies of the relationship between coccolithophore assemblages and ocean geochemistry also provide evidence of a relationship between coccolithophorid calcification and carbonate chemistry (e.g., Cubillos et al., 2007; Tyrell et al., 2008; Beaufort et al., 2008).

However, in a series of very recent laboratory experiments, Iglesias-Rodriguez et al. (2008a) and Shi et al. (2009) report quite the opposite response to many previous experiments increased rather than decreased calcification at higher ambient $\mathrm{CO}_{2}$ (and lower $\mathrm{pH}$ and $\Omega$ ). Even when normalized to cellular POC production (Riebesell et al., 2008) the response is qualitatively very different (Table 1 ). Interspecific variability in the $\mathrm{CO}_{2}$-sensitivity of calcification has also previously been documented. For example, Coccolithus pelagicus and Calcidiscus leptoporus grown in laboratory mono-cultures exhibit no consistent trend in calcification as a function of $\mathrm{CO}_{2}$ (Langer et al., 2006), while Gephyrocapsa oceanica, a genetically very similar species to $E$. huxleyi, responds with a very substantial decrease in calcification at high $\mathrm{CO}_{2}$ conditions (Riebesell et al., 2000; Zondervan et al., 2001).

It is important to resolve this apparent incongruence in calcification responses to simulated ocean acidification if we are to draw reliable implications from experimental manipulations regarding expected future ocean acidification impacts on marine ecosystems. A strong $\mathrm{CO}_{2}$-dependence of calcification rates has implications for ocean carbon cycling and would provide a negative feedback on atmospheric $\mathrm{CO}_{2}$ increases (Ridgwell et al., 2007b; Zondervan et al., 2001) since calcification decreases seawater alkalinity and releases $\mathrm{CO}_{2}$ from bicarbonate $\left(\mathrm{HCO}_{3}^{-}\right)$in the upper ocean. Changes in the production of biogenic $\mathrm{CaCO}_{3}$ minerals at the ocean surface could potentially also affect the transport of particulate organic carbon (POC) to depth (Armstrong et al., 2002; Klaas and Archer, 2002) and act to increase atmospheric $\mathrm{CO}_{2}$ via a reduction in the efficiency of the biological pump. Global carbon cycle models used for projecting future global carbon cycle changes must account for observed phenomena and base their parameterizations for calcification closely on such results (e.g., Gehlen et al., 2007; Heinze, 2004; Hofmann and Schellnhuber, 2009; Ridgwell et al., 2007a, b), and these model predictions will be unreliable if rooted in unrepresentative or misunderstood laboratory observations.

In addition to potential calcification impacts, higher ambient concentrations of dissolved $\mathrm{CO}_{2}$ and acidification have been observed in the laboratory to result in a greater production of organic matter per cell in phytoplankton (Riebesell et al., 2007; Bellerby et al., 2007; Zondervan et al., 2002). Increased photosynthetic fixation of carbon and subsequent removal from surface waters as sinking particulate organic matter would decrease the concentration of dissolved $\mathrm{CO}_{2}$ at the ocean surface and thus accelerate the uptake of fossil fuel $\mathrm{CO}_{2}$ from the atmosphere. However, for the strength of the biological pump to be increased there must be sufficient nutrients. A commensurate decrease in the amount of nitrogen and phosphorus required per unit quantity of carbon fixed would facilitate this as it would allow nutrients to be utilized more "efficiently", an effect that the results of mesocosm 
Table 1. Synthesis of available coccolithophorid calcification carbonate chemistry manipulation experiments.

\begin{tabular}{|c|c|c|c|c|c|c|c|c|c|}
\hline 莺 & 咅 & 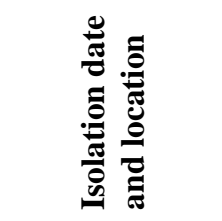 & 氞 & 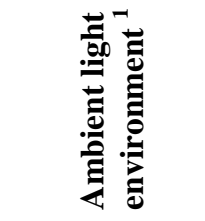 & 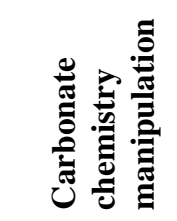 & 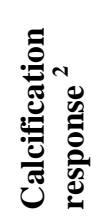 & 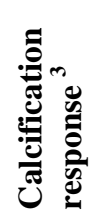 & 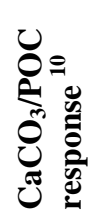 & 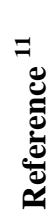 \\
\hline Emiliania huxleyi & $\begin{array}{l}\text { NZEH } \\
\text { (CAWPO6) }\end{array}$ & $\begin{array}{l}1992 \\
\text { South Pacific }\end{array}$ & $\begin{array}{l}\text { laboratory } \\
\text { culture }\end{array}$ & $\begin{array}{l}\text { 12:12 h L:D } \\
150 \mu \mathrm{mol} \mathrm{m}^{-2} \mathrm{~s}^{-1}\end{array}$ & $\mathrm{CO}_{2}$ bubbling & $\uparrow$ & $\uparrow$ & $\leftrightarrow$ & 1 \\
\hline Emiliania huxleyi & MBA $61 / 12 / 4$ & $\begin{array}{l}1991 \\
\text { North Atlantic }\end{array}$ & $\begin{array}{l}\text { laboratory } \\
\text { culture }\end{array}$ & $\begin{array}{l}\text { 12:12 h L:D } \\
150 \mu \mathrm{mol} \mathrm{m}^{-2} \mathrm{~s}^{-1}\end{array}$ & $\mathrm{CO}_{2}$ bubbling & $\uparrow$ & $\uparrow$ & $\mathrm{n} / \mathrm{a}$ & 1 \\
\hline Emiliania huxleyi & $\begin{array}{l}\text { PML } \\
\text { B92/11A }\end{array}$ & $\begin{array}{l}1992 \\
\text { North Sea }\end{array}$ & $\begin{array}{l}\text { laboratory } \\
\text { culture }\end{array}$ & $\begin{array}{l}\text { 18:6 h L:D } \\
150 \mu \mathrm{mol} \mathrm{m}^{-2} \mathrm{~s}^{-1}\end{array}$ & acid/base & $\mathrm{n} / \mathrm{a}$ & $\downarrow$ & $\downarrow$ & 2,5 \\
\hline Emiliania huxleyi & $\begin{array}{l}\text { PML } \\
\text { B92/11A }\end{array}$ & $\begin{array}{l}1992 \\
\text { North Sea }\end{array}$ & $\begin{array}{l}\text { laboratory } \\
\text { culture }\end{array}$ & $\begin{array}{l}\text { 24:0 h L:D } \\
150 \mu \mathrm{mol} \mathrm{m}^{-2} \mathrm{~s}^{-1}\end{array}$ & acid/base & $\mathrm{n} / \mathrm{a}$ & $\downarrow$ & $\downarrow$ & 2,5 \\
\hline Emiliania huxleyi & ССMP 371 & $\begin{array}{l}1987 \\
\text { Sargasso Sea }\end{array}$ & $\begin{array}{l}\text { laboratory } \\
\text { culture }\end{array}$ & $\begin{array}{l}\text { 12:12 h L:D } \\
50 \mu \mathrm{mol} \mathrm{m}^{-2} \mathrm{~s}^{-1}\end{array}$ & $\mathrm{CO}_{2}$ bubbling & $\leftrightarrow$ & $\mathrm{n} / \mathrm{a}$ & $\downarrow$ & 3 \\
\hline Emiliania huxleyi & CCMP 371 & $\begin{array}{l}1987 \\
\text { Sargasso Sea }\end{array}$ & $\begin{array}{l}\text { laboratory } \\
\text { culture }\end{array}$ & $\begin{array}{l}\text { 12:12 h L:D } \\
400 \mu \mathrm{mol} \mathrm{m}^{-2} \mathrm{~s}^{-1}\end{array}$ & $\mathrm{CO}_{2}$ bubbling & $\downarrow$ & $\mathrm{n} / \mathrm{a}$ & $\downarrow$ & 3 \\
\hline Emiliania huxleyi & TW1 & $\begin{array}{l}2001 \\
\text { W Mediterranean }\end{array}$ & $\begin{array}{l}\text { laboratory } \\
\text { culture }\end{array}$ & $\begin{array}{l}\text { 24:0 h L:D } \\
570 \mu \mathrm{mol} \mathrm{m}^{-2} \mathrm{~s}^{-1}\end{array}$ & $\mathrm{CO}_{2}$ bubbling & $\downarrow$ & $\downarrow$ & $\leftrightarrow$ & 4 \\
\hline Emiliania huxleyi & $88 \mathrm{E}$ & $\begin{array}{l}1988 \\
\text { Gulf of Maine }\end{array}$ & $\begin{array}{l}\text { laboratory } \\
\text { culture }\end{array}$ & $\begin{array}{l}24: 0 \mathrm{~h} \mathrm{~L}: \mathrm{D} \\
50 \mu \mathrm{mol} \mathrm{m}^{-2} \mathrm{~s}^{-1}\end{array}$ & acid/base & $\mathrm{n} / \mathrm{a}$ & $\leftrightarrow^{4}$ & $\leftrightarrow^{4}$ & 9 \\
\hline Emiliania huxleyi & Ch 24-90 & $\begin{array}{l}1991 \\
\text { North Sea }\end{array}$ & $\begin{array}{l}\text { laboratory } \\
\text { culture }\end{array}$ & $\begin{array}{l}\text { 16:8 h L:D } \\
300 \mu \mathrm{mol} \mathrm{m}^{-2} \mathrm{~s}^{-1}\end{array}$ & $\mathrm{CO}_{2}$ bubbling & $\mathrm{n} / \mathrm{a}$ & $\leftrightarrow^{5}$ & $\leftrightarrow^{5}$ & 10 \\
\hline Emiliania huxleyi & $\begin{array}{l}\text { NZEH } \\
\text { (PLY M219) }\end{array}$ & $\begin{array}{l}1992 \\
\text { South Pacific }\end{array}$ & $\begin{array}{l}\text { laboratory } \\
\text { culture }\end{array}$ & $\begin{array}{l}\text { 24:0 h L:D } \\
150 \mu \mathrm{mol} \mathrm{m}^{-2} \mathrm{~s}^{-1}\end{array}$ & acid/base & $\uparrow$ & $\uparrow$ & $\leftrightarrow$ & 11 \\
\hline $\begin{array}{l}\text { Gephyrocapsa } \\
\text { oceanica }\end{array}$ & PC7/1 & $\begin{array}{l}1998 \\
\text { Portuguese shelf }\end{array}$ & $\begin{array}{l}\text { laboratory } \\
\text { culture }\end{array}$ & $\begin{array}{l}\text { 18:6 h L:D } \\
150 \mu \mathrm{mol} \mathrm{m}^{-2} \mathrm{~s}^{-1}\end{array}$ & acid/base & $\mathrm{n} / \mathrm{a}$ & $\downarrow$ & $\downarrow$ & 2,5 \\
\hline $\begin{array}{l}\text { Calcidiscus } \\
\text { leptoporus }\end{array}$ & AC365 & $\begin{array}{l}2000 \\
\text { South Atlantic }\end{array}$ & $\begin{array}{l}\text { laboratory } \\
\text { culture }\end{array}$ & $\begin{array}{l}\text { 16:8 h L:D } \\
350 \mu \mathrm{mol} \mathrm{m}^{-2} \mathrm{~s}^{-1}\end{array}$ & acid/base & $\mathrm{n} / \mathrm{a}$ & $\downarrow^{6}$ & $\downarrow^{6}$ & 6 \\
\hline $\begin{array}{l}\text { Coccolithus } \\
\text { pelagicus }\end{array}$ & AC400 & $\begin{array}{l}2000 \\
\text { South Atlantic }\end{array}$ & $\begin{array}{l}\text { laboratory } \\
\text { culture }\end{array}$ & $\begin{array}{l}\text { 16:8 h L:D } \\
350 \mu \mathrm{mol} \mathrm{m}^{-2} \mathrm{~s}^{-1}\end{array}$ & acid/base & $\mathrm{n} / \mathrm{a}$ & $\leftrightarrow$ & $\leftrightarrow$ & 6 \\
\hline Emiliania huxleyi ${ }^{7}$ & $\mathrm{n} / \mathrm{a}$ & $\begin{array}{l}\text { n/a } \\
\text { (North Sea) }\end{array}$ & mesocosm $^{8}$ & $\begin{array}{l}\text { 95\% of ambient } \\
\text { surface } \\
\text { irradiance }\end{array}$ & $\mathrm{CO}_{2}$ bubbling & $\mathrm{n} / \mathrm{a}$ & $\downarrow^{9}$ & $\downarrow^{9}$ & 7,8 \\
\hline $\begin{array}{l}\text { subarctic North } \\
\text { Pacific } \\
\text { natural } \\
\text { assemblages }\end{array}$ & $\mathrm{n} / \mathrm{a}$ & $\begin{array}{l}\text { n/a } \\
\text { (N. Pacific) }\end{array}$ & $\begin{array}{l}\text { ship-board } \\
\text { incubation }\end{array}$ & $\begin{array}{l}30 \% \text { of ambient } \\
\text { surface } \\
\text { irradiance }\end{array}$ & $\mathrm{CO}_{2}$ bubbling & $\mathrm{n} / \mathrm{a}$ & $\downarrow^{9}$ & $\downarrow^{9}$ & 2 \\
\hline $\begin{array}{l}\text { subarctic North } \\
\text { Pacific } \\
\text { natural } \\
\text { assemblages }\end{array}$ & $\mathrm{n} / \mathrm{a}$ & $\begin{array}{l}\text { n/a } \\
\text { (N. Pacific) }\end{array}$ & $\begin{array}{l}\text { ship-board } \\
\text { incubation }\end{array}$ & $\begin{array}{l}30 \% \text { of ambient } \\
\text { surface } \\
\text { irradiance }\end{array}$ & acid/base & $\mathrm{n} / \mathrm{a}$ & $\downarrow^{9}$ & $\downarrow^{9}$ & 2 \\
\hline
\end{tabular}

${ }^{1}$ Light: dark irradiance cycle in hours light vs. dark per $24 \mathrm{~h}$ cycle; irradiance as the photon flux density associated with the "light" period.

${ }^{2} \mathrm{Sign}$ of the calcification response of plankton at elevated $(\sim \times 2$ to $\times 3)$ compared to modern $\mathrm{CO}_{2}$. The size of the arrow indicates the sensitivity of calcification response in a simple: "very low" ( $\downarrow)$, "low" ( $\downarrow)$, "medium” $(\downarrow)$, "high" $(\downarrow)$ classification, with "medium" representing an approximate halving (or doubling) of calcification in resposne to a ca. $\times 2-3$ increase in $\mathrm{CO}_{2}$. Red represents a decrease in calcification in response to higher $\mathrm{CO}_{2}$ (lower $\mathrm{pH}$ ), while blue $(\uparrow)$ is a calcification increase. Green $(\leftrightarrow)$ is no significant or consistent response. The calcification change is calculated from observations reported in units of mol (or $\mathrm{g}$ ) of $\mathrm{CaCO}_{3}$ (or $\mathrm{C}$ ) per cell.

${ }^{3} \mathrm{As}^{2}$, except change in calcification in units of mol (or g) of $\mathrm{CaCO}_{3}$ (or C) per cell per day (or hour). The difference between ${ }^{2}$ and ${ }^{3}$ reflects any change in growth rate $\left(\mu, \mathrm{d}^{-1}\right.$ ) at elevated $\mathrm{CO}_{2}$.

${ }^{4}$ Experimental carbonate chemistry modification was qualitatively very different from the effect of increased $\mathrm{CO}_{2}$ alone and some treatments had very low DIC, questioning its applicability to future conditions in the ocean.

${ }_{5}$ Results of the constant alkalinity experiment, which was the only manipulation similar to the effect of future $\mathrm{CO}_{2}$ addition. However, alkalinity used $\left(1214 \mu \mathrm{eq} \mathrm{1}^{-1}\right)$ was only about half that found in the modern open ocean, questioning its applicability.

6 "Optimum" $\mathrm{CO}_{2}$-calcification response curve - no consistent trend with $\mathrm{CO}_{2}$, but reduced calcification at $800-900 \mathrm{ppm}$.

${ }^{7}$ Emiliania huxleyi was the dominant (calcifying) plankton species in the induced mesocosm bloom.

${ }^{8}$ Enclosed body of seawater in each mesocosm was approximately $11000 \mathrm{~L}$ volume.

${ }^{9}$ Reported as an integrated production rate in units of mol (or g) carbon per unit volume per unit time.

${ }^{10} \mathrm{CaCO}_{3} / \mathrm{POC}$ - response of calcification normalized by response of POC production to ocean acidification.

${ }^{11}$ References: (1) Iglesias-Rodriguez et al. (2008), (2) Riebesell et al. (2000), (3) Feng et al. (2008), (4) Sciandra et al. (2003), (5) Zondervan et al. (2001), (6) Langer et al. (2006), (7) Delille et al. (2005), (8) Engel et al. (2005), (9) Nimer and Merrett (1993), (10) Buitenhuis et al. (1999), (11) Shi et al. (2009). 
experiments support (Riebesell et al., 2007; Bellerby et al., 2007). However, additional feedbacks as nutrient-to-carbon ratios change may also become important and limit productivity (Thingstad et al., 2008). Because current uncertainties of acidification impacts on cellular organic matter composition are large and no global models yet routinely incorporate this effect in predicting future atmospheric $\mathrm{CO}_{2}$ concentrations, we focus on the better studied consequence of ocean acidification for calcification.

In this paper we summarize and assess the current state of knowledge provided by experimental manipulations of coccolithophores (Sect. 3) and outline a thought experiment to help interpret apparently conflicting experimental observations and guide model development and their future projections (Sect. 4). We start with an overview of the importance to atmospheric $\mathrm{CO}_{2}$ of ocean acidification impacts on pelagic (coccolithophore) calcification and how this is currently treated in models (Sect. 2), and end with some conclusions and perspectives (Sect. 5).

\section{Global carbon cycle impacts of ocean acidification in models}

By precipitating calcium carbonate $\left(\mathrm{CaCO}_{3}\right)$ from sea-water, marine organisms play an active role in regulating the global carbon cycle and thus climate system. In the net chemical reaction for creating carbonate shells and skeletons:

$\mathrm{Ca}^{2+}+2 \mathrm{HCO}_{3}^{-} \rightarrow \mathrm{CaCO}_{3}+\mathrm{CO}_{2(\mathrm{aq})}+\mathrm{H}_{2} \mathrm{O}$

dissolved inorganic carbon in seawater, in the form of the bicarbonate ion $\left(\mathrm{HCO}_{3}^{-}\right)$which itself cannot interact directly with the atmosphere, is converted into dissolved $\mathrm{CO}_{2}\left(\mathrm{CO}_{2(\mathrm{aq})}\right)$ as a consequence of the removal of alkalinity (as $\mathrm{Ca}^{2+}$ ) during calcification. Although it is carbonate ions $\left(\mathrm{CO}_{3}^{2-}\right)$ that are incorporated in the $\mathrm{CaCO}_{3}$ crystal lattice, because there is continuous re-equilibrium between the different species of the aqueous carbonate system, Eq. (2) is as equally valid as writing the alternative: $\mathrm{Ca}^{2+}+\mathrm{CO}_{3}^{2-} \rightarrow \mathrm{CaCO}_{3}$ (Wolf-Gladrow et al., 2007), and the ultimate re-equilibrated carbonate state after calcification (higher $\mathrm{CO}_{2(\mathrm{aq})}$, lower $\mathrm{HCO}_{3}^{-}$and $\mathrm{CO}_{3}^{2-}$ ) will be the same. Conversely, reducing the rate of calcification globally would reduce surface $\left[\mathrm{CO}_{2(\mathrm{aq})}\right]$ and hence increase the uptake of $\mathrm{CO}_{2}$ from the atmosphere. In the example of fossil fuel emissions and increasing atmospheric $p \mathrm{CO}_{2}$, changes in calcification may provide a negative feedback on climate change.

There is a second reason for correctly representing the carbonate production response to ocean acidification in models - because mineral $\mathrm{CaCO}_{3}$ is much denser than the soft body parts of plankton, the presence of $\mathrm{CaCO}_{3}$ in aggregates with organic matter may be important in accelerating the rate of sinking of particulate organic carbon (POC) (Armstrong et al., 2002; Klaas and Archer, 2002). In this "ballast hypothesis", any reduction in calcification by plankton at the ocean surface would increase the time that POC was suspended in the warm upper ocean and increase the likelihood of its being consumed by the more numerous and more active bacteria present there (Turley and Mackie, 1994). A reduction in the efficiency of the biological pump and hence transport of POC to depth would thus create a positive feedback on rising atmospheric $\mathrm{CO}_{2}$.

Only a few global models have so far been applied to quantifying the importance of changing pelagic carbonate production on the oceans ability to sequester $\mathrm{CO}_{2}$. Although the $\mathrm{CO}_{2}$-calcification feedback was initially assessed in box models (Barker et al., 2003), the first ocean GCM to account for this effect was the HAMOCC model (Six and MaierReimer, 1996), in which Heinze (2004) parameterized the net ecosystem $\mathrm{CaCO}_{3}: \mathrm{POC}$ export ratio $\left(R^{\mathrm{CaCO}_{3} / \mathrm{POC}}\right)$ as a function of the ambient $\mathrm{CO}_{2(\mathrm{aq})}$ concentration $\left(\left[\mathrm{CO}_{2(\mathrm{aq})}\right]\right)$ :

$R^{\mathrm{CaCO}_{3} / \mathrm{POC}}=R_{\max }^{\mathrm{CaCO}_{3} / \mathrm{POC}} \cdot\left(1-0.012 \cdot\left(\mathrm{CO}_{2}-\mathrm{CO}_{2(0)}\right)\right)(3)$ where $\mathrm{CO}_{2}$ is the current $\mathrm{CO}_{2(\mathrm{aq})}$ concentration $\left(\mu \mathrm{mol} \mathrm{l}{ }^{-1}\right)$, $\mathrm{CO}_{2(0)}$ is preindustrial $\left[\mathrm{CO}_{2(\mathrm{aq})}\right]$, and $R_{\max }^{\mathrm{CaCO}_{3} / \mathrm{POC}}$ is assigned a value of 0.15 . (Further modifications are made in the model to $R^{\mathrm{CaCO}_{3} / \mathrm{POC}}$ according to inferred diatom productivity.) The strength of the relationship between $\mathrm{CaCO}_{3}: \mathrm{POC}$ and $\left[\mathrm{CO}_{2(\mathrm{aq})}\right]$ was taken directly from the E. huxleyi carbonate chemistry manipulation response reported by Zondervan et al. (2001).

Gehlen et al. (2007), in the ocean GCM/biogeochemical model OCM-PISCES (Gehlen et al., 2006), generalized their parameterization of the $\mathrm{CO}_{2}$-calcification response by including the newly available results of mesocosm experiments (Delille et al., 2005) in addition to laboratory manipulations (Zondervan et al., 2002). For the form of the empirical fit to the observed data, Gehlen et al. (2007) assumed a hyperbolic function for their parameterization, akin to the Monod equation relating phytoplankton growth to nutrient concentrations:

$R^{\mathrm{CaCO}_{3} / \mathrm{POC}}=R_{\max }^{\mathrm{CaCO}_{3} / \mathrm{POC}} \cdot \frac{\left(\Omega_{c}-1\right)}{K_{\max }+\left(\Omega_{c}-1\right)}$

where $R_{\max }^{\mathrm{CaCO}_{3} / \mathrm{POC}}=0.8, \Omega_{c}$ is the ambient saturation state with respect to calcite, and $K_{\max }$ is assigned a value of 0.4 .

Ridgwell et al. (2007a, b) utilized established abiotic precipitation kinetics as the basis for their description of marine carbonate production, in an equation of the form:

$$
\begin{aligned}
& R^{\mathrm{CaCO}_{3} / \mathrm{POC}}=R_{0}^{\mathrm{CaCO}_{3} / \mathrm{POC}} \cdot(\Omega-1)^{\eta} \text { for } \Omega>1.0 \\
& R^{\mathrm{CaCO}_{3} / \mathrm{POC}}=0.0 \text { for } \Omega \leq 1.0
\end{aligned}
$$

where $\eta$ is a power setting the non-linearity of the calcification response to changes in ambient saturation state and $R_{0}^{\mathrm{CaCO}_{3} / \mathrm{POC}}$ the base $\mathrm{CaCO}_{3}: \mathrm{POC}$ export ratio. In Ridgwell et al. (2007b), the implications of a range of potential values for $\eta$ were considered, spanning available observations 
from a variety of different experimental manipulations, while requiring consistency with observed ocean geochemical patterns. The central estimate was with $\eta=0.81$.

Finally, in a recent study, Hofmann and Schellnhuber (2009) incorporated the box-model parameterization of Barker et al. (2003) into the ocean-atmosphere-sea ice-biogeochemistry model "POTSMOM-C" (Hofmann and Schellnhuber, 2009):

$R^{\mathrm{CaCO}_{3} / \mathrm{POC}}=e^{0.0083 \cdot\left(\mathrm{CO}_{3}^{2-}-\mathrm{CO}_{3(0)}^{2-}\right)}$

where $\mathrm{CO}_{3}^{2-}$ is the current ambient carbonate ion concentration $\left(\mu \mathrm{moll}^{-1}\right)$ and $\mathrm{CO}_{3(0)}^{2-}$ is assigned a value of $150 \mu \mathrm{moll}^{-1}$.

The predicted additional quantity of fossil fuel $\mathrm{CO}_{2}$ taken up by the ocean $\left(\Delta \mathrm{CO}_{2}\right)$ by the year 2100 due to reduced calcification across the different ocean-carbon cycle GCMs ranges from 5.9 to $23.4 \mathrm{PgC}$ (Fig. 1a). Some of this spread is due to methodological differences, as three of the studies use varying $\mathrm{CO}_{2}$ emissions scenarios while Gehlen et al. (2007) take a different approach entirely and prescribe an atmospheric $p \mathrm{CO}_{2}$ trajectory. Making the model comparison at a single point in time (year 2100) means that atmospheric $p \mathrm{CO}_{2}$ differs somewhat between the models. In contrast, making a comparison when a particular value of $p \mathrm{CO}_{2}$ has been reached would mean that calcification will have been suppressed for longer in some models than in others, which will also influence $\Delta \mathrm{CO}_{2}$ (Ridgwell et al., 2007b). Either way (normalizing to year, or normalizing to $p \mathrm{CO}_{2}$ reached), the spread in model $\Delta \mathrm{CO}_{2}$ predictions appears to be approximately a factor of 4 . However, other aspects of global models also differ, such as parameterizations of $\mathrm{CaCO}_{3}$ dissolution in the water column, and the initial state of ocean circulation its response to global warming etc. Of particular relevance here is the fact that initial global $\mathrm{CaCO}_{3}$ export is not consistent across models (and differs by a factor of 2). Hence, even if the relative pelagic calcification response was the same in each model, the absolute change in the strength of $\mathrm{CaCO}_{3}$ export and marine carbonate cycling and thus $\Delta \mathrm{CO}_{2}$ would differ. Normalizing $\triangle \mathrm{CO}_{2}$ to initial global $\mathrm{CaCO}_{3}$ export production reduces the inter-model spread of $\mathrm{CO}_{2}$ uptake response to a little over a factor 2 (Fig. 1b).

Much of the residual $\Delta \mathrm{CO}_{2}$ variability between models is likely to reflect differences in the assumed sensitivity and non-linearity of model carbonate production to ocean acidification. In constructing the $\mathrm{CO}_{2}$-calcification parameterizations, each model was informed by different sub-sets of available experimental observations, giving 4 different interpretations of the form of the ocean acidification response (Eqs. 3-6). We are left asking: How important is the uncertainty in the sensitivity of the calcification response to ocean acidification to estimates of future ocean $\mathrm{CO}_{2}$ uptake (parameter uncertainty)? And: is the chosen form (i.e., equation) of the calcification dependence (i.e., model structural

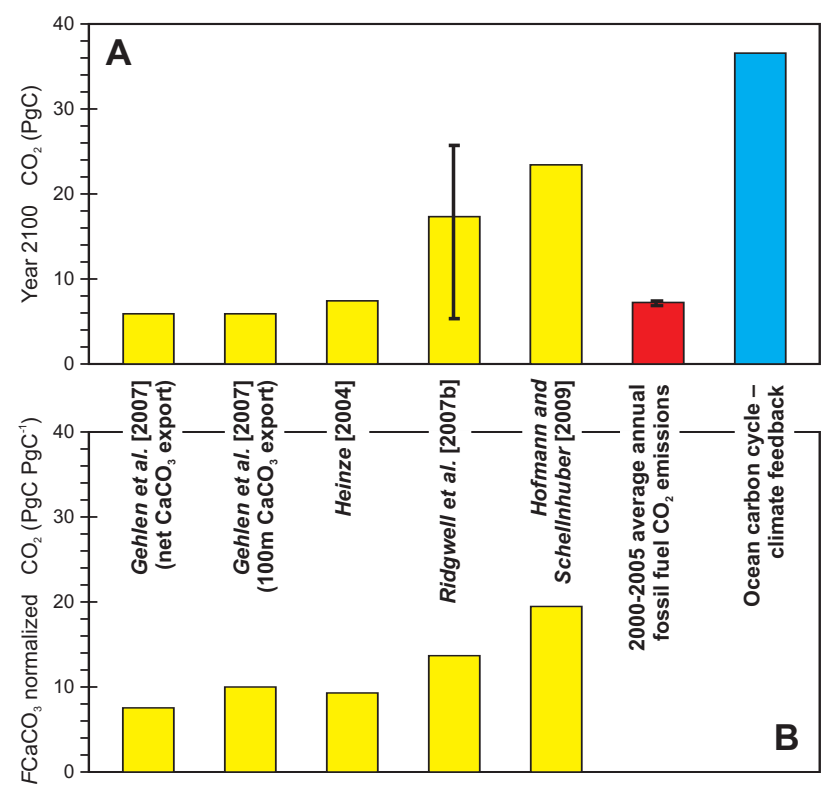

Fig. 1. Predicted strength of the $\mathrm{CO}_{2}$-calcification feedback. (A) Model predictions for the increased $\mathrm{CO}_{2}$ uptake by the ocean $\left(\Delta \mathrm{CO}_{2}\right)$ by the year 2100 due to reduced calcification. The error bars for the estimate of Ridgwell et al. (2007b) reflect the spread of the model ensemble. Note that the assumed $\mathrm{CO}_{2}$ emissions or atmospheric concentration trajectory differ somewhat between studies and there is no consistency between the studies as to whether climate feedbacks are included or not, although all are loosely "business as usual". However, the basic results are unchanged if $\Delta \mathrm{CO}_{2}$ is instead calculated for an atmospheric $p \mathrm{CO}_{2}$ of $\sim 1150 \mu \mathrm{atm}$. Shown for comparison is the estimated 2000-2005 rate of fossil fuel consumption and cement production $\left(7.2 \pm 0.3 \mathrm{PgC} \mathrm{yr}^{-1}\right.$ ) (Denman et al., 2007). Also shown is an estimate of the year 2100 strength of the ocean carbon cycle feedback to climate change - the additional $\mathrm{CO}_{2}$ remaining in the atmosphere due to ocean surface warming and changes in circulation but excluding any change in carbonate production using the 16 ocean level GENIE-1 Earth system model (see Cao et al., 2009 for model description and experimental design). However, it should be recognized that this estimate is just part of the overall $\mathrm{CO}_{2}$-climate feedback as it excludes any terrestrial biosphere response which is more important again (Friedlingstein et al., 2006). (B) Model predicted year $2100 \Delta \mathrm{CO}_{2}$ normalized by initial (baseline) global $\mathrm{CaCO}_{3}$ export, which for the different models (left-to-right) is: $0.79 \mathrm{PgC} \mathrm{yr}^{-1}$ (net $\mathrm{CaCO}_{3}$ production of Gehlen et al., 2007), $0.59 \mathrm{PgC} \mathrm{yr}^{-1}\left(\mathrm{CaCO}_{3}\right.$ export at $100 \mathrm{~m}$ of Gehlen et al., 2007), 0.8 $\mathrm{PgC} \mathrm{yr}^{-1}$ (Heinze, 1994), 1.26 $\mathrm{PgC} \mathrm{yr}^{-1}$ (ensemble mean) (Ridgwell et al., 2007b), and $1.20 \mathrm{PgC} \mathrm{yr}^{-1}$ (Hofmann and Schellnhuber, 2009).

uncertainty) important? Some insight into the sources of predictive uncertainty can be made using a single model and parameterization, but with an ensemble of differing model $\mathrm{CO}_{2}$-calcification sensitivities accounting for the broad range of calcification responses observed in laboratory manipulation experiments. In just such a modeling exercise, the predictions of enhanced year $2100 \mathrm{CO}_{2}$ uptake were found 
to span $5.4 \mathrm{PgC}$ to $25.7 \mathrm{PgC}$, with an ensemble mean of 17.2 PgC (Ridgwell et al., 2007b). This range is comparable to that of the variability between different models, suggesting that the uncertainty in species calcification response and their relative importance for carbonate production globally is likely dominating the overall uncertainty in model predictions of fossil fuel $\mathrm{CO}_{2}$ uptake by the ocean (Fig. 1).

This simple over-view ignores the question of mineral ballasting of particulate organic matter transport as fewer still global ocean models have assessed $\mathrm{CO}_{2}$-calcification together with "ballasting". For instance, Hofmann and Schellnhuber (2009) found a $\sim 6 \mathrm{PgC}(27 \%)$ reduction in $\Delta \mathrm{CO}_{2}$ due to reduced $\mathrm{CaCO}_{3}$ ballasting. Other studies have hinted that as much as $80 \%$ of the $\mathrm{CO}_{2}$-calcificiation feedback could be negated (Heinze, 2004), while Barker et al. (2003) predicted a reversal is possible, with more fossil fuel $\mathrm{CO}_{2}$ overall residing in the atmosphere, i.e., a negative value for $\Delta \mathrm{CO}_{2}$. However, the importance of mineral ballasting in the transport of organic matter to depth is currently highly uncertain (Francois et al., 2002; Passow and De La Rocha, 2006). In addition, we have discussed only marine carbonate production by coccolithophore phytoplankton. Up to $50 \%$ of the modern pelagic carbonate production globally may instead be by calcifying zooplankton - foraminifera, while aragonite shell producing pterodpods are thought to contribute at the $\sim 10 \%$ level (Schiebel, 2002). But we will focus here on coccolithophores, who have the more developed (however currently incomplete) laboratory characterization.

\section{Reconciling observed coccolithophorid manipulation responses}

The potential carbon cycle roles and feedbacks with climate involving the production and fate of calcite liths requires that we better constrain the magnitude of the response. To this end, and to help make better sense of experimental observations and improve model parameterizations, we have compiled the pertinent details of available coccolithophorid manipulations and their differing calcification responses to elevated $\mathrm{CO}_{2}$ and lower $\mathrm{pH}$ and carbonate saturation (Table 1). While irradiance levels and nutrient regime may vary substantially between experiments and potentially be important (Riebesell et al., 2008), we will concentrate in this paper on: species (and strain), experimental design, and chemistry manipulation. Because there is neither a common baseline $\mathrm{CO}_{2}$ concentration that is used across all experiments, nor consistent degree of acidification (or $\mathrm{CO}_{2}$ concentration increase/decrease) in the experimental manipulation, or even a single unit for reporting calcification, we have deliberately characterized the calcification response qualitatively rather than quantitatively, as described in Table 1 .
This compilation can firstly be used to test the explanation proposed by Iglesias-Rodriguez et al. $(2008 \mathrm{a}, \mathrm{b})$ - that the difference between the chemical manipulations performed is critical, with direct acid/base chemistry manipulation (e.g., Riebesell et al., 2000; Zondervan et al., 2001) inducing an erroneous response to ocean acidification compared to $\mathrm{CO}_{2}$ bubbling (e.g., Iglesias-Rodriguez et al., 2008a). Both types of manipulations are capable of producing the same $\mathrm{pH}$ or $p \mathrm{CO}_{2}$ changes - bubbling with $\mathrm{CO}_{2}$ increases $\left[\mathrm{CO}_{2(\mathrm{aq})}\right]$, $\left[\mathrm{HCO}_{3}^{-}\right]$and DIC, leaves alkalinity unaffected, and decreases $\mathrm{pH}$ and $\left[\mathrm{CO}_{3}^{2-}\right]$. Adding acid, decreases alkalinity, $\mathrm{pH}$ and $\left[\mathrm{CO}_{3}^{2-}\right]$, increases $\left[\mathrm{CO}_{2(\mathrm{aq})}\right]$ and $\left[\mathrm{HCO}_{3}^{-}\right]$but leaves DIC constant. Consequently, in both manipulations: $\left[\mathrm{CO}_{2(\mathrm{aq})}\right]$ (and hence $p \mathrm{CO}_{2}$ ) and $\left[\mathrm{HCO}_{3}^{-}\right]$increase, while $\mathrm{pH},\left[\mathrm{CO}_{3}^{2-}\right]$ and saturation state $(\Omega)$ decrease (Table 2). However, the basis of the argument is that the changes in bicarbonate $\left(\mathrm{HCO}_{3}^{-}\right)$concentrations will differ (Iglesias-Rodriguez et al., $2008 \mathrm{~b}$ ) which could potentially influence the response of both organic and inorganic carbon fixation if $\mathrm{HCO}_{3}^{-}$is the substrate used (Buitenhuis et al., 1999; Paasche, 2002).

The carbonate parameters resulting from $\mathrm{CO}_{2}$ bubbling (changing total dissolved carbon, DIC) to a target $p \mathrm{CO}_{2}$ $\left(\left[\mathrm{CO}_{2(\mathrm{aq})}\right]\right)$ compared to acid/base addition (changing alkalinity, ALK) to either explicitly match the $p \mathrm{CO}_{2}$ target or replicate the $\mathrm{pH}$ change achieved by bubbling, are summarized in Table 2. We argue that the differences in carbonate parameters between the different manipulations are not critical. For instance, going from pre-industrial like conditions (278 ppm) to approximately year $2100 \mathrm{CO}_{2}$ (twice modern, $780 \mathrm{ppm}$ ) produces a $17 \%$ increase in $\mathrm{HCO}_{3}^{-}$concentrations by $\mathrm{CO}_{2}$ bubbling, and about half this with acid/base addition, while all other carbonate parameters are very comparable between manipulation methods (and see Schulz et al., 2009). If changes in bicarbonate ion concentration were to dominate the calcification response, manipulation experiments carried out by acid/base addition will, if anything, underestimate acidification impacts. Otherwise, if $\left[\mathrm{CO}_{2(\mathrm{aq})}\right],\left[\mathrm{CO}_{3}^{2-}\right]$ and/or $\left[\mathrm{H}^{+}\right](\mathrm{pH})$ are important, experimental bias will be minimal. The generation of a reversed response seems unlikely. Indeed, recent laboratory experiments performed on E. huxleyi (strain: PLY M219) in which carbonate chemistry was performed by both $\mathrm{CO}_{2}$ bubbling and acid/base addition, found no observable difference in the response (Shi et al., 2009).

Considering all reported coccolithophorid observations and associated experimental details (Table 1), there is no evidence of any systematic correlation between the direction of calcification response under simulated future conditions and type of chemical manipulation. Furthermore, shipboard incubations in which chemical manipulation was carried out by both methods exhibit similar suppressions of carbonate production at higher $\mathrm{CO}_{2}$ (Riebesell et al., 2000). Thus, we rule out the possibility of a consistent methodological bias between $\mathrm{CO}_{2}$ bubbling and acid/base addition that produces 
Table 2. Behaviour of carbonate parameters in response to $\mathrm{CO}_{2}$ bubbling vs. acid/base manipulation. Numbers in bold assume a $\mathrm{CO}_{2}$ bubbling like change, i.e., ALK is held constant and $p \mathrm{CO}_{2}$ adjusted. Numbers in normal text assume ALK is changed in order to match the $\mathrm{pH}$ change by $\mathrm{CO}_{2}$ bubbling (red). Numbers in italics assume ALK is changed in order to match the $p \mathrm{CO}_{2}$ change by $\mathrm{CO}_{2}$ bubbling (blue). The carbonate chemistry starting point $(278 \mathrm{ppm})$ is shaded in grey. Calculations assume a temperature of $20^{\circ} \mathrm{C}$ and salinity of $35 \mathrm{PSU}$ and atmospheric pressure $\left(0 \mathrm{~m}\right.$ water depth), and $0 \mu \mathrm{mol} \mathrm{kg}{ }^{-1}\left[\mathrm{PO}_{4}^{3-}\right]$ and $\left[\mathrm{H}_{4} \mathrm{SiO}_{4}\right]$, and were made using the "CO2SYS" program $(\mathrm{Lewis}$ and Wallace, 1998), with $K_{1}$ and $K_{2}$ from Mehrbach et al. (1973) as refit by Dickson and Millero (1987) and $K_{\mathrm{SO}_{4}}$ from Dickson (1990).

\begin{tabular}{llllllll}
\hline$p \mathrm{CO}_{2}(\mu \mathrm{atm})$ & $\begin{array}{l}\mathrm{DIC} \\
\left.(\mu \mathrm{mol} \mathrm{kg})^{-1}\right)\end{array}$ & $\begin{array}{l}\mathrm{ALK} \\
\left.(\mu \mathrm{mol} \mathrm{kg})^{-1}\right)\end{array}$ & $\begin{array}{l}{\left[\mathrm{CO}_{2(\mathrm{aq})}\right]} \\
\left.(\mu \mathrm{mol} \mathrm{kg})^{-1}\right)\end{array}$ & $\begin{array}{l}{\left[\mathrm{HCO}_{3}{ }^{-}\right]} \\
\left.(\mu \mathrm{mol} \mathrm{kg})^{-1}\right)\end{array}$ & $\begin{array}{l}{\left[\mathrm{CO}_{3}{ }^{2}\right]} \\
\left.(\mu \mathrm{mol} \mathrm{kg})^{-1}\right)\end{array}$ & $p \mathrm{H}_{(\mathrm{SWS})}$ & $\Omega$ (calcite) \\
\hline $\mathbf{1 9 0 . 0}$ & $\mathbf{1 8 8 2 . 2}$ & $\mathbf{2 3 0 0 . 0}$ & $\mathbf{6 . 1}$ & $\mathbf{1 5 8 7 . 7}$ & $\mathbf{2 8 8 . 4}$ & $\mathbf{8 . 2 9 4}$ & $\mathbf{6 . 9 0}$ \\
198.1 & 1967.3 & 2397.5 & 6.4 & 1659.7 & 301.2 & 8.294 & 7.20 \\
190.0 & 1967.3 & 2411.8 & 6.1 & 1649.8 & 311.4 & 8.311 & 7.45 \\
\hline $\mathbf{2 7 8 . 0}$ & $\mathbf{1 9 6 7 . 3}$ & $\mathbf{2 3 0 0 . 0}$ & $\mathbf{9 . 0}$ & $\mathbf{1 7 2 5 . 5}$ & $\mathbf{2 3 2 . 8}$ & $\mathbf{8 . 1 6 5}$ & $\mathbf{5 . 5 7}$ \\
278.0 & 1967.3 & 2300.0 & 9.0 & 1725.5 & 232.8 & 8.165 & 5.57 \\
278.0 & 1967.3 & 2300.0 & 9.0 & 1725.5 & 232.8 & 8.165 & 5.57 \\
\hline $\mathbf{3 9 0 . 0}$ & $\mathbf{2 0 3 7 . 1}$ & $\mathbf{2 3 0 0 . 0}$ & $\mathbf{1 2 . 6}$ & $\mathbf{1 8 3 6 . 5}$ & $\mathbf{1 8 8 . 0}$ & $\mathbf{8 . 0 4 5}$ & $\mathbf{4 . 5 0}$ \\
377.0 & 1967.3 & 2224.0 & 12.2 & 1773.7 & 181.4 & 8.045 & 4.34 \\
390.0 & 1967.3 & 2216.3 & 12.6 & 1778.4 & 176.3 & 8.031 & 4.22 \\
\hline $\mathbf{5 6 0 . 0}$ & $\mathbf{2 1 0 4 . 2}$ & $\mathbf{2 3 0 0 . 0}$ & $\mathbf{1 8 . 1}$ & $\mathbf{1 9 4 0 . 0}$ & $\mathbf{1 4 6 . 1}$ & 7.912 & $\mathbf{3 . 4 9}$ \\
523.6 & 1967.3 & 2154.8 & 16.9 & 1813.8 & 136.6 & 7.912 & 3.27 \\
560.0 & 1967.3 & 2142.1 & 18.1 & 1820.6 & 128.7 & 7.884 & 3.08 \\
\hline $\mathbf{7 8 0 . 0}$ & $\mathbf{2 1 5 8 . 8}$ & $\mathbf{2 3 0 0 . 0}$ & $\mathbf{2 5 . 2}$ & $\mathbf{2 0 1 9 . 9}$ & $\mathbf{1 1 3 . 7}$ & 7.786 & $\mathbf{2 . 7 2}$ \\
710.2 & 1967.3 & 2100.8 & 22.9 & 1840.7 & 103.7 & 7.786 & 2.48 \\
780.0 & 1967.3 & 2085.8 & 25.2 & 1847.0 & 95.1 & 7.747 & 2.27 \\
\hline
\end{tabular}

a spurious calcification response in one direction or the other, an inference supported by Shi et al. (2009).

Some of the degree of apparent disparity between experiments may be an artifact of commonly reported units for calcification (e.g., $\mathrm{CaCO}_{3}$ per cell) and normalizing $\mathrm{CaCO}_{3}$ production to POC production produces greater consistency between experiments (Riebesell et al., 2008), with no study reporting significantly increased $\mathrm{CaCO}_{3} / \mathrm{POC}$ with ocean acidification (Table 1). Assuming no change in nutrient supply or nutrient utilization (but see e.g., Riebesell et al., 2007; Bellerby et al., 2007) the value of $\mathrm{CaCO}_{3} / \mathrm{POC}$ rather than $\mathrm{CaCO}_{3}$ per cell is more helpful to estimating impacts on global carbonate production. Indeed, in global models (Sect. 2) it is always the $\mathrm{CaCO}_{3} / \mathrm{POC}$ ratio that is parameterized (e.g., as a function of carbonate chemistry) rather than $\mathrm{CaCO}_{3}$ production explicitly. However, in normalizing the ocean acidification calcification response to $\mathrm{CaCO}_{3} / \mathrm{POC}$ it is noticeable there is a disparity between monospecific laboratory culture experiments and shipboard manipulations of diverse assemblages, with generally increased POC production in the former (e.g., Iglesias-Rodríguez et al., 2008; Riebesell et al., 2000; Shi et al., 2009) and reduced in the latter (Riebesell et al., 2000), although some culture experiments also show reduced POC at higher $p \mathrm{CO}_{2}$ (e.g., Sciandra et al., 2003). Potentially, the shipboard manipulation experiments encapsulate a community-wide response of POC production across the plankton assemblage. Alternatively, the more nutrient limiting conditions of natural seawater samples compared to the nutrient replete conditions of laboratory cul- tures may be important in determining the sign of the POC response to ocean acidification.

Notable in our compilation are differences in the strain of E. huxleyi used. Given that different investigators have used different strains of E. huxleyi (Table 1), much of the incongruence between observed responses across studies could result from differing ecological adaptation (ecotypes). Additionally, the strains used have been in culture for differing periods ranging from several years to decades and may have partially adapted after capture to the chemical conditions in the stock medium which are significantly different from sea water. Thus, the intra-species variability across experiments on E. huxleyi may be analogous to less controversial interspecific variability that has been reported amongst obviously different species (e.g., Langer et al., 2006).

The coccolithophore E. huxleyi is in fact thought to be a "species complex", encompassing a wide range of genotypic variation. This is suggested by the extraordinarily broad ecological and biogeographic distribution of the species, and by its morphological variability (Paasche, 2002). This inference has been supported by a range of culture experiment work, (e.g. Brand, 1982; Young and Westbroek, 1991), and molecular genetic studies (Schroeder et al., 2005; IglesiasRodríguez et al., 2006). It is now conventionally recognized that E. huxleyi includes at least five morphologically discrete varieties or sub-species (Young et al., 2003). However, it is likely that this is a gross simplification since both field and culture observations reveal considerably more variability. As illustrated in Fig. 2, the observed degree of calcification of 

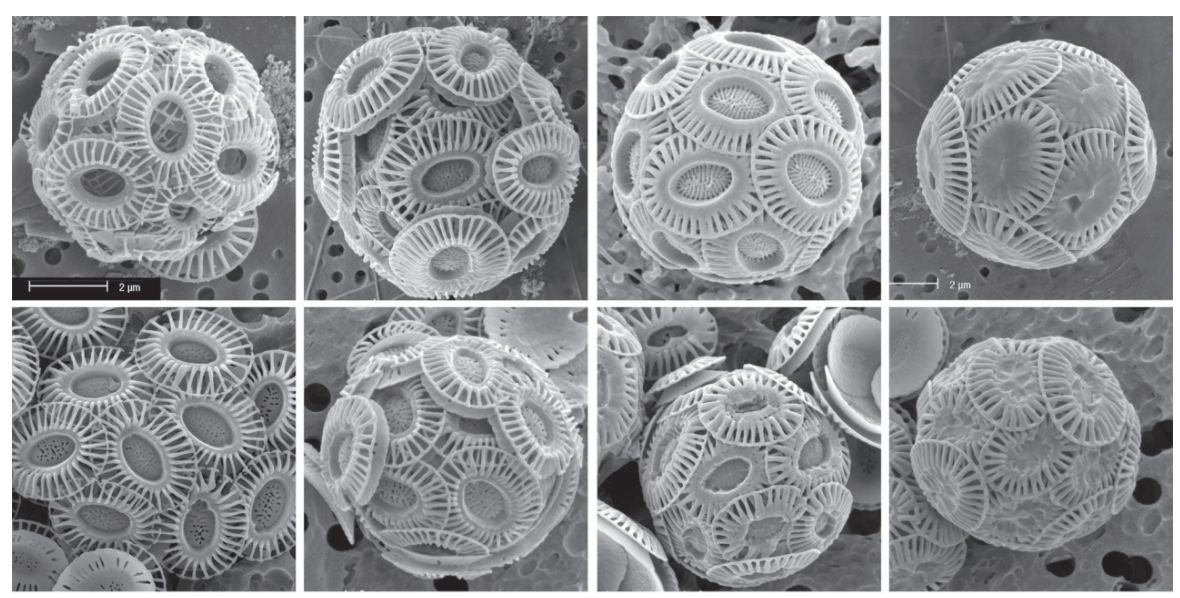

Fig. 2. Observed natural and laboratory variability in Emiliania huxleyi calcification. Top row: Emiliania huxleyi from plankton samples showing highly variable calcification, and with no sign of overgrowth or etching. Bottom row: four different Emiliania huxleyi strains grown under similar conditions and illustrating range of variability shown between strains. All images taken at the same magnification.

coccoliths, both in the field as well as in culture under similar environmental conditions, varies substantially. At least visually, the natural variability present between different strains appears equal to or exceeds that due to culturing experiments under varying $p \mathrm{CO}_{2}$ (e.g., Riebesell et al., 2000). Arguably we should regard E. huxleyi as a diverse assemblage of genotypes with highly variable calcification characteristics and ecological adaptations. The substantial variability in degree of calcification between genotypes suggests that future changes in genotype assemblage could be important.

\section{The "Eppley Curve" as a thought experiment for the pelagic calcification response to ocean acidification}

Individual phytoplankton species generally exhibit a pronounced growth response curve to temperature; with a growth rate maximum $\left(\mu_{\max }\right)$ corresponding to optimum conditions and lower growth under the sub-optimal conditions either side of this. It would be impossible to represent explicitly this behavior in all plankton species individually in global ocean carbon cycle models, so instead the temperature response at the ecosystem or "functional type" (Le Quéré et al., 2005) level is simulated. In this respect, Eppley (1972) noted that given a sufficiently large species sample size, the envelope of the individual growth-temperature response curves could be delineated by a simple function of temperature (Fig. 3):

$\mu_{\max }=0.851 \cdot(1.066)^{T}$

(Eppley, 1972). Or more commonly - writing growth rate in units of per day $\left(\mathrm{d}^{-1}\right)$ : $\mu_{\max }=0.59 \cdot e^{0.0633 \cdot T}$

(Bissinger et al., 2008), the difference being a factor of $\ln (2)$ (Moisan et al., 2002).

This equation encapsulates the progressive transition in dominance amongst different plankton species as a function of changing temperature. The Eppley curve thus negates the need to resolve the potential presence and specific characteristics of a myriad of individual species, by instead focusing on the community level response. As a result, the Eppley function has found favor in many global carbon cycle and ecosystem models for predicting phytoplankton growth rates (e.g., Aumont et al., 2003; Schmittner et al., 2008; Six and Maier-Reimer, 1996) and recent re-analyses based on larger data-sets have not led to any significant change in the details of this equation (Bissinger et al., 2008). However, it should be noted that the accuracy of this approximation becomes somewhat degraded in conditions of rapid species transition and dominance such as during a spring bloom (Moisan et al., 2002) or the dynamically varying environment of estuaries (Brush et al., 2002), while the temperature dependence of photosynthetic rates and chlorophyll concentrations in surface waters is better described in alternative ways (Behrenfeld and Falkowski, 1997).

We suggest that drawing parallels with the net calcification of a community as a function of carbonate chemistry may be instructive. In particular, we hypothesize that a shift in ecosystem composition between species (or sub-species) with differing degrees of calcification is important and may dominate over the calcification response of any one particular species to changes in carbonate chemistry (illustrated in annotations to Fig. 3). The apparently increased sensitivity of carbonate production of natural assemblages relative to laboratory cultures (Table 1, Ridgwell et al., 2007b) provides some support for our interpretation. This may reflect 


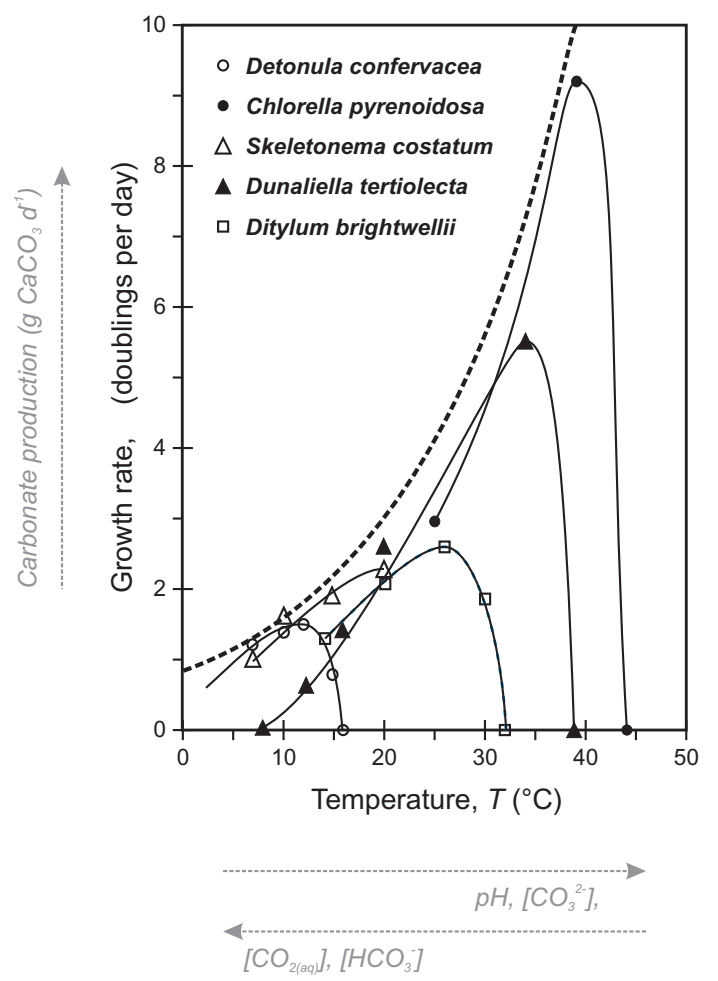

Fig. 3. Eppley curve encapsulation of temperature-growth behavior. Growth rates vs. temperature curves (solid lines) for five different (non-calcifying) unicellular algae with different temperature optima (redrawn from Eppley, 1972). Shown is the derived Eppley net ecosystem temperature-growth response curve (thick dashed line) (Eq. 7). Shown for illustration purposes is our conceptual analogy for the $\mathrm{CO}_{2}$-calcification system (axis labels in grey and italics) involving a relationship between environmental carbonate chemistry and net ecosystem calcification. However, a different picture may emerge if calcification if normalized as $\mathrm{CaCO}_{3} / \mathrm{POC}$.

an amplification of acidification impacts on carbonate production via changes in the species and ecotype composition of calcifying phytoplankton assemblages, in addition to direct physiological impacts on the calcification of individual species. The responses observed in the few shipboard incubations (Riebesell et al., 2000) and mesocosm experiments (Delille et al., 2005; Engel et al., 2005) carried out to date, all manipulations with comparatively complete natural plankton assemblages, also appear highly consistent in showing substantial decrease in community carbonate production at higher $\mathrm{CO}_{2}$ and lower saturation (Table 1). Furthermore, the co-variation between saturation state and morphotype of E. huxleyi observed across the subantarctic and Polar Fronts in the Southern Ocean, with less heavily calcified ecotypes dominant at lower saturation state is consistent with our model (Cubillos et al., 2007). In addition, Tyrell et al. (2008) argued that the absence of E. huxleyi in the Baltic but presence in the Black Sea cannot be explained by salinity or temperature but could be a result of calcite satura- tion state, while Beaufort et al. (2008) inferred that size and weight of coccoliths of Isochrysidales (predominantly Emiliania and Gephyrocapsa) through the Pacific Ocean correlates with carbonate system parameters, and especially alkalinity.

The difference in growth rate vs. carbonate chemistry relationships between two distinct monoclonal cultures of $E$. huxleyi reported by Iglesias-Rodriguez et al. (2008a) hints at a mechanism for succession by less heavily calcified ecotypes in the open ocean. In these experiments, the less calcified strain (MBA 61/12/4) exhibits less growth rate sensitivity to higher $\mathrm{CO}_{2}$ conditions (M. D. Iglesias-Rodriguez, personal communication, 2009) than the more heavily calcified strain (CAWPO6) and under the $750 \mathrm{ppm} \mathrm{CO}_{2}$ treatment, MBA 61/12/4 becomes the faster growing strain. Preferential suppression of cell division rate of more heavily calcified ecotypes at higher $\mathrm{CO}_{2}$ is consistent with the open ocean observations of Cubillos et al. (2007) and raises the possibility of succession by less heavily calcified ecotypes in the open ocean in the future.

With respect to the Eppley curve - whether any particularly close analogy holds is difficult to say. For temperature and growth rate, sampling just a few species taken from differing environments creates the potential for conflicting experimental observations, depending upon the position of the experimental growth position relative to the species optimum (i.e. above or below). It is thus possible to identify a temperature at which the optimum of a cold-adapted species is exceeded; leading to slower growth rates with increasing temperature, while a warm-adapted species exhibits increased growth rates with increasing temperature (temperature below the optimum). Could this help explain the apparently conflicting positive vs. negative observed calcification response? Unfortunately, there is currently only a small sample size available and only in a single experiment carried out across future-relevant carbonate chemistry changes has a clear calcification "optimum" been observed (Langer et al., 2006) (Table 1) - the remainder of the data-set, at best, is sampling incomplete portions of an optimum curve which must then be generally broad. Why an environmental optimum for calcification should even exist is also not as obvious as for growth vs. temperature, particularly in why calcification should decline for $\mathrm{pH}$ or saturation higher than the optimum. Instead, if carbonate chemistry changes affect growth rate with the relative impact differing with some relationship to the degree of calcification (as discussed above with respect to 2 different strains of E. huxleyi), then a closer analogy with the Eppley curve might exist. Clearly, improved process understanding of the calcification mechanisms at work, the "purpose" of making liths, and the cellular cost of their production, is required to be able to judge the degree to which analogy with the Eppley curve can helpfully be made. 


\section{Conclusions and perspectives}

The integrated ocean carbon cycle response as imprinted on the ocean alkalinity field may not be observable any sooner than ca. 30 years from now (Ilyina et al., 2009). While historical and deeper-time geological studies may help quantitatively link ecosystem-level calcification impacts to ocean acidification, laboratory studies will continue to provide key information on the range of potential responses of different ecotypes and on the mechanisms by which changes occur in response to changes in carbonate chemistry. This will be essential in refining the structure of models through better process based understanding of individuals physiology. However, the extraordinary diversity in calcification behavior and environmental sensitivity exhibited by different ecotypes (e.g., of E. huxleyi) make laboratory studies with monospecific cultures prone to producing conflicting results and model studies must avoid basing parameterizations on small subsets of experimental observations. Because the results of single strain studies are far removed from the net impact of higher $\mathrm{CO}_{2}$ (lower $\mathrm{pH}$ and saturation) on diverse, natural assemblages in-situ, mesocosm experiments and shipboard manipulations carried out in a variety of oceanic regions are essential to improving our predictive capabilities of ecosystem level behavior and net community calcification. Indeed, in the shorter-term, such studies may more readily inform practical relationships between carbonate production and ocean chemistry in global models.

With regards to the type of experimental manipulation, we find no evidence that it impacts an experimental bias. However, Shi et al. (2009) noted poorer experimental reproducibility due to the mechanical agitation of the cultures under bubbling, while the addition of $\mathrm{pH}$ buffers might affect trace metal speciation and hence availability. It is interesting that the different chemistry manipulations find some parallel with natural ocean chemistry changes occurring on differing time-scales. The decadal to century-scale time-scale of emissions and subsequent surface water dissolution and ocean invasion of fossil fuel $\mathrm{CO}_{2}$ is closest to bubbling because the dominant buffering is internal to ocean surface aqueous carbonate system. However, on a thousand to ten thousand year time-scale, once $\mathrm{CO}_{2}$ dissolved at the surface has been mixed to depth in the ocean, lower saturation drives an increased dissolution of $\mathrm{CaCO}_{3}$ in deep-sea sediments in a reverse of the precipitation reaction (Eq. 2):

$$
\mathrm{CaCO}_{3}+\mathrm{CO}_{2(\mathrm{aq})}+\mathrm{H}_{2} \mathrm{O} \rightarrow \mathrm{Ca}^{2+}+2 \mathrm{HCO}_{3}^{-}
$$

and hence neutralizing some of the $\mathrm{CO}_{2}$ acidity. Further buffering of ocean chemistry and atmospheric $p \mathrm{CO}_{2}$ is provided by imbalances induced between weathering of limestone and chalks $\left(\mathrm{CaCO}_{3}\right)$ on land and suppressed $\mathrm{CaCO}_{3}$ burial in the ocean (Archer et al., 1997; Ridgwell and Zeebe, 2005). Geological events such as the glacial-interglacial cycles of the past few hundred thousand years, while involving significant changes in $p \mathrm{CO}_{2}$, because the time-scale is much slower than current human disturbance and ocean chemistry is buffered by sedimentary $\mathrm{CaCO}_{3}$ will involve significant changes in bicarbonate. Hence, acid/base addition could be viewed as "closer" to glacial-interglacial changes in ocean chemistry as opposed to contemporary fossil fuel invasion, although strictly speaking, because the glacial-interglacial cycles also involved an important component of emission (glacial) and removal (interglacial) of $\mathrm{CO}_{2}$ to the terrestrial biosphere (Kohfeld and Ridgwell, 2009) they represent a combination of bubbling and acid/base change.

An analogy between the net ecosystem calcification response to ocean acidification and the "Eppley curve" for growth rate with changing temperature is consistent with: monoclonal laboratory observations of preferential growth rate suppression in more heavily calcified species (IglesiasRodriguez et al., 2008a), transitions from more to less heavily calcified morphotypes across saturation gradients in the ocean (Cubillos et al., 2007), and a greater net calcification response in natural plankton assemblages relative to monospecific cultures (Ridgwell et al., 2007b). Although the evidence for individual species exhibiting calcification "optima" is limited, as a thought experiment, this may prove useful in helping bridge the gap between experimental manipulations and global models and improve model predictions of future fossil fuel $\mathrm{CO}_{2}$ uptake. A closer analogy may even exist mediated via growth impacts of carbonate chemistry changes. A similar conceptual approach might also prove fruitful in addressing the ocean acidification impacts on the other major pelagic carbonate producers - foraminifers.

Regardless of the form and sensitivity of the calcification parameterization, it should be recognized that the direct impact of calcification changes on atmospheric $\mathrm{CO}_{2}$ through the remainder of this century is relatively small compared to anticipated annual emissions as well as to other carbon cycle feedbacks. For instance, yearly emissions of $\mathrm{CO}_{2}$ from the burning of fossil fuels and cement production averaged some $7.2 \pm 0.3 \mathrm{PgC} \mathrm{yr}^{-1}$ over 2000-2005 (Denman et al., 2007) this is of comparable magnitude to the entire 100-year integrated impact of reduced calcification of $\sim 6-23 \mathrm{PgC}$. The predicted year 2100 repartitioning of $\mathrm{CO}_{2}$ from atmosphere to ocean due to reduced calcification is also dwarfed by the anthropogenic $\mathrm{CO}_{2}$ inventories of the ocean and atmosphere, which even in 1994 stood at 118 and $165 \mathrm{PgC}$, respectively (Sabine et al., 2004), as well as by the importance of feedbacks such as between temperature and $\mathrm{CO}_{2}$ solubility. Hence, future research should progressively shift towards understanding ecosystem level changes and impacts as well as reducing the currently unreasonably large uncertainty in the initial (modern) state and operation of marine carbon cycling, particularly with respect to the global $\mathrm{CaCO}_{3}$ budget and the mechanisms by which particulate organic matter is transported to the deep sea. 
Acknowledgements. A. R. and D. S. acknowledge support from The Royal Society in the form of University Research Fellowships. C. T. acknowledges funding from the NERC funded Oceans 2025 programme. This work is a contribution to the "European Project on Ocean Acidification" (EPOCA) which received funding from the European Community's Seventh Framework Programme (FP7/2007-2013) under grant agreement no. 211384. This paper benefitted from the helpful and inteligent reviewing of Christoph Heinze, Marion Gehlen, Jelle Bijma, and a 4th (anomyous) referee.

Edited by: U. Riebesell

\section{References}

Archer, D., Kheshgi, H., and Maier-Reimer, E.: Multiple timescales for neutralization of fossil fuel $\mathrm{CO}_{2}$, Geophys. Res. Lett., 24, 405-408, 1997.

Armstrong, R. A., Lee, C., Hedges, J. I., Honjo, S., and Wakeham, S. G.: A new, mechanistic model for organic carbon fluxes in the ocean: Based on the quantitative association of POC with ballast minerals, Deep Sea Res. II, 49, 219-236, 2002.

Aumont, O., Maier-Reimer, E., Blain, S., and Monfray, P.: An ecosystem model of the global ocean including $\mathrm{Fe}$, $\mathrm{Si}$, P colimitations, Global Biogeochem. Cy., 17(2), 1060, doi:10.1029/2001GB001745, 2003.

Barker, S., Higgins, J. A., and Elderfield, H.: The future of the carbon cycle: review, calcification response, ballast and feedback on atmospheric $\mathrm{CO}_{2}$, Philos. T. Roy. Soc. A, 361, 1977-1999, 2003.

Beaufort, L., Couapel, M., Buchet, N., Claustre, H., and Goyet, C.: Calcite production by coccolithophores in the south east Pacific Ocean, Biogeosciences, 5, 1101-1117, 2008, http://www.biogeosciences.net/5/1101/2008/.

Behrenfeld, M. J. and Falkowski, P. G., Photosynthetic Rates Derived from Satellite-based Chlorophyll Concentration, Limnol. Oceanogr., 42, 1-20, 1997.

Bellerby, R. G. J., Schulz, K. G., Riebesell, U., Neill, C., Nondal, G., Heegaard, E., Johannessen, T., and Brown, K. R.: Marine ecosystem community carbon and nutrient uptake stoichiometry under varying ocean acidification during the PeECE III experiment, Biogeosciences, 5, 1517-1527, 2008, http://www.biogeosciences.net/5/1517/2008/.

Bissinger, J. E., Montagnes, D. J. S., Sharples, J., and Atkinson, D.: Predicting marine phytoplankton maximum growth rates from temperature: Improving on the Eppley curve using quantile regression, Limnol. Oceanogr., 53, 487-493, 2008.

Brand, L. E.: Genetic variability and spatial patterns of genetic differentiation in the reproductive rates of the marine coccolithophores Emiliania huxleyi and Gephyrocapsa oceanica, Limnol. Oceanogr., 27(2), 236-245, 1982.

Brush, M. J., Brawley, J. W., Nixon, S. W., and Kremer, J. N.: Modeling phytoplankton production. Problems with the Eppley Curve and an empirical alternative, Mar. Ecol. Prog. Ser., 238, 31-45, 2002.

Buitenhuis, E., de Baar, H., and Veldhuis, M.: Photosynthesis and calcification in Emiliania huxleyi as a function of inorganic carbon species, J. Phycol., 35, 949-959, 1999.
Caldeira, K. and Wickett, M. E.: Anthropogenic carbon and ocean pH, Nature, 425, p. 365, 2003.

Cao, L., Eby, M., Ridgwell, A., Caldeira, K., Archer, D., Ishida, A., Joos, F., Matsumoto, K., Mikolajewicz, U., Mouchet, A., Orr, J. C., Plattner, G.-K., Schlitzer, R., Tokos, K., Totterdell, I., Tschumi, T., Yamanaka, Y., and Yool, A.: The role of ocean transport in the uptake of anthropogenic $\mathrm{CO}_{2}$, Biogeosciences, 6, 375-390, 2009, http://www.biogeosciences.net/6/375/2009/.

Cubillos, J. C, Wright, S. W., Nash, G., de Salas, M. F., et al.: Calcification morphotypes of the coccolithophorid Emiliania huxleyi in the Southern Ocean: changes in 2001 to 2006 compared to historical data, Mar. Ecol. Prog. Ser., 348, 47-54, 2007.

Delille, B., Harlay, J., Zondervan, I., et al.: Response of primary production and calcification to changes of $p \mathrm{CO}_{2}$ during experimental blooms of the coccolithophorid Emiliania huxleyi, Global Biogeochem. Cy., 19, GB2023, doi:10.1029/2004GB002318, 2005.

Denman, K. L., Brasseur, G., Chidthaisong, A., Ciais, P., et al.: Couplings Between Changes in the Climate System and Biogeochemistry. In: Climate Change 2007: The Physical Science Basis. Contribution of Working Group I to the Fourth Assessment Report of the Intergovernmental Panel on Climate Change, edited by: Solomon, S., Qin, D., Manning, M., Chen, Z., Marquis, M., Averyt, K. B., Tignor, M., and Miller, H. L., Cambridge University Press, Cambridge, 2007.

Dickson, A. G.: Standard potential of the reaction: $\mathrm{AgCl}(\mathrm{s})+1 / 2$ $\mathrm{H} 2(\mathrm{~g})=\mathrm{Ag}(\mathrm{s})+\mathrm{HCl}(\mathrm{aq})$, and the standard acidity constant of the ion $\mathrm{HSO}_{4}^{-}$in synthetic seawater from 273.15 to $318.15 \mathrm{~K}$, J. Chem. Thermodyn., 22, 113-127, 1990.

Dickson, A. G. and Millero, F. J.: A comparison of the equilibrium constants for the dissociation of carbonic acid in seawater media, Deep-Sea Res., 34, 1733-1743, 1987.

Engel, A., Zondervan, I., Aerts, K., Beaufort, L., et al.: Testing the direct effect of $\mathrm{CO}_{2}$ concentration on a bloom of the coccolithophorid Emiliania huxleyi in mesocosm experiments, Limnol. Oceanogr., 50, 493-507, 2005.

Eppley, R. W.: Temperature and phytoplankton growth in the sea, Fish. Bull., 70, 1063-1085, 1972.

Feng, Y., Warner, M. E., Zhang, Y., Sun, J., Fu, F.-X., Rose, J. M., and Hutchins, D. A.: Interactive effects of increased $p \mathrm{CO}_{2}$, temperature and irradiance on the marine coccolithophore Emiliania huxleyi (Prymnesiophyceae), European J. Phycol., 43, 8798, 2008.

Francois, R., Honjo, S., Krishfield, R., and Manganini, S.: Factors controlling the flux of organic carbon to the bathypelagic zone of the ocean, Global Biogeochem. Cy., 16, 1087, doi:10.1029/2001GB001722, 2002.

Gehlen, M., Bopp, L., Emprin, N., Aumont, O., Heinze, C., and Ragueneau, O.: Reconciling surface ocean productivity, export fluxes and sediment composition in a global biogeochemical ocean model, Biogeosciences, 3, 521-537, 2006, http://www.biogeosciences.net/3/521/2006/.

Gehlen, M., Gangst $\varnothing$, R., Schneider, B., Bopp, L., Aumont, O., and Ethe, C.: The fate of pelagic $\mathrm{CaCO}_{3}$ production in a high $\mathrm{CO}_{2}$ ocean: a model study, Biogeosciences, 4, 505-519, 2007, http://www.biogeosciences.net/4/505/2007/.

Heinze, C.: Simulating oceanic $\mathrm{CaCO}_{3}$ export production in the greenhouse, Geophys. Res. Lett., 13, L16308, 
doi:10.1029/2004GL020613, 2004.

Hofmann, M. and Schellnhuber, H.-J.: Oceanic acidification affects marine carbon pump and triggers extended marine oxygen holes, P. Natl. Acad. Sci., 106, 3017-3022, 2009.

Iglesias-Rodríguez, M. D., Schofield, O., Batley, J., Medlin, L. K., and Hayes, P. K.: Intraspecific genetic diversity in the marine coccolithophore Emiliania huxleyi (Prymnesiophyceae): the use of microsatellite analysis in marine phytoplankton population studies, J. Phycol., 42, 526-536, 2006.

Iglesias-Rodriguez, M. D., Halloran, P. R., Rickaby, R. E. M., Hall, I. R., et al.: Phytoplankton calcification in a high- $\mathrm{CO}_{2}$ world, Science, 320, 336-340, 2008a.

Iglesias-Rodriguez, M. D., Buitenhuis, E. T., Raven, J. A., Schofield, O., et al.: Response to Comment on "Phytoplankton Calcification in a High- $\mathrm{CO}_{2}$ World", Science, 322, 1466c, doi:10.1126/science.1161501, 2008b.

Ilyina, T., Zeebe, R. E., Maier-Reimer, E., and Heinze, C.: Early detection of ocean acidification effects on marine calcification, Global Biogeochem. Cy., 23, GB1008, doi:10.1029/2008GB003278, 2009.

Klaas, C. and Archer, D. E.: Association of sinking organic matter with various types of mineral ballast in the deep sea: Implications for the rain ratio, Global Biogeochem. Cy., 16, 1116, doi:10.1029/2001GB001765, 2002.

Kohfeld, K. E. and Ridgwell, A.: Glacial-interglacial variability in atmospheric $\mathrm{CO}_{2}$, in: Surface Ocean - Lower Atmospheres Processes, edited by: Saltzman, E. and Le Quéré, C., AGU Geophysical Monograph Series, in press, 2009.

Langer G., Geisen, M., Baumann, K.-H., Kläs, J., Riebesell, U., Thoms, S., and Young, J. R.: Species-specific responses of calcifying algae to changing seawater carbonate chemistry, Geochem. Geophys. Geosyst., 7, Q09006, doi:10.1029/2005GC001227, 2006.

Le Quéré, C., Harrison, S. P., Colin Prentice, I., Buitenhuis, E. T., Aumont, O., Bopp, L., Claustre, H., Cotrim da Cunha, L., Geider, R., Giraud, X., Klaas, C., Kohfeld, K. E., Legendre, L., Manizza, M., Platt, T., Rivkin, R. B., Sathyendranath, S., Uitz, J., Watson, A. J., and Wolf-Gladrow, D.: Ecosystem dynamics based on plankton functional types for global ocean biogeochemistry models, Glob. Change Biol., 11, 2016-2040, doi:10.11111/j.1365-2486.2005.01004.x, 2005.

Lewis, E. and Wallace, D. W. R.: Program Developed for $\mathrm{CO}_{2}$ System Calculations. ORNL/CDIAC-105, Carbon Dioxide Information Analysis Center, Oak Ridge National Laboratory, US Department of Energy, Oak Ridge, Tennessee, 1998.

Mehrbach, C., Culberson, C. H., Hawley, J. E., and Pytkowicz, R. M.: Measurement of the apparent dissociation constants of carbonic acid in seawater at atmospheric pressure, Limnol. Oceanogr., 18, 897-907, 1973.

Moisan, J. R., Moisan, T. A., and Abbott, M. R.: Modelling the effect of temperature on the maximum growth rates of phytoplankton populations, Ecol. Model., 153, 197-215, 2002.

Nimer, N. A. and Merrett, M. J.: Calcification rate in Emiliania huxleyi Lohmann in response to light, nitrate and availability of inorganic carbon, New Phytol., 123, 673-677, 1993.

Paasche, E.: A Review of the Coccolithophorid Emiliania huxleyi (Prymnesiophyceae), with Particular Reference to Growth, Coccolith Formation, and Calcification-Photosynthesis Interactions, Phycologia, 40, 503-529, 2002.
Passow, U. and De La Rocha, C. L.: Accumulation of mineral ballast on organic aggregates, Global Biogeochem. Cy., 20, GB1013, doi:10.1029/2005GB002579, 2006.

Ridgwell, A.: Changes in the mode of carbonate deposition: Implications for Phanerozoic ocean chemistry, Mar. Geol., 217, 339357, 2005.

Ridgwell, A. and Zeebe, R. E.: The role of the global carbonate cycle in the regulation and evolution of the Earth system, Earth Planet. Sci. Lett., 234, 299-315, 2005.

Ridgwell, A., Hargreaves, J. C., Edwards, N. R., Annan, J. D., Lenton, T. M., Marsh, R., Yool, A., and Watson, A.: Marine geochemical data assimilation in an efficient Earth System Model of global biogeochemical cycling, Biogeosciences, 4, 87-104, 2007a, http://www.biogeosciences.net/4/87/2007/.

Ridgwell, A., Zondervan, I., Hargreaves, J. C., Bijma, J., and Lenton, T. M.: Assessing the potential long-term increase of oceanic fossil fuel $\mathrm{CO}_{2}$ uptake due to $\mathrm{CO}_{2}$-calcification feedback, Biogeosciences, 4, 481-492, 2007b, http://www.biogeosciences.net/4/481/2007/.

Riebesell, U., Zondervan, I., Rost, B., Tortell, P. D., Zeebe, R. E., and Morel, F. M. M.: Reduced calcification of marine plankton in response to increased atmospheric $\mathrm{CO}_{2}$, Nature, 407, 364-367, 2000.

Riebesell, U., Schulz, K. G., Bellerby, R. G. J., Botros, M., Fritsche, P., Meyerhöfer, M., Neill, C., Nondal, G., Oschlies, A., Wohlers, J., and Zöllner, E.: Enhanced biological carbon consumption in a high $\mathrm{CO}_{2}$ ocean, Nature, 450, 545-548, 2007.

Riebesell, U., Bellerby, R. G. J., Engel, A., Fabry, V. J., et al.: Comment on "Phytoplankton Calcification in a High- $\mathrm{CO}_{2}$ World", Science, 322, 1466b, doi:10.1126/science.1161096, 2008.

Sabine C. L., et al.: The oceanic sink for anthropogenic $\mathrm{CO}_{2}$, Science 305, 367-371, 2004.

Schmittner, A., Oschlies, A., Matthews, H. D., and Galbraith, E. D.: Future changes in climate, ocean circulation, ecosystems and biogeochemical cycling simulated for a business-as-usual $\mathrm{CO}_{2}$ emission scenario until year $4000 \mathrm{AD}$, Global Biogeochem. Cy., 22, GB1013, doi:10.1029/2007GB002953, 2008.

Schroeder, D. C., Biggi, G. F., Hall, M., Davy, J., Martinez, J. M., Richardson, A. J., Malin, G., and Wilson, W. H.: A genetic marker to separate Emiliania huxleyi (Prymnesiophyceae) morphotypes, J. Phycol., 41, 874-879, 2005.

Schulz, K. G., Barcelos e Ramos, J., Zeebe, R. E., and Riebesell, U.: $\mathrm{CO}_{2}$ perturbation experiments: similarities and differences between dissolved inorganic carbon and total alkalinity manipulations, Biogeosciences, 6, 2145-2153, 2009, http://www.biogeosciences.net/6/2145/2009/.

Sciandra, A., Harlay, J., Lefèvre, D., Lemée, R., Rimmelin, P., Denis, M., and Gattuso, J. P.: Response of coccolithophorid Emiliania huxleyi to elevated partial pressure of $\mathrm{CO}_{2}$ under nitrogen limitation, Mar. Ecol. Prog. Ser., 261, 111-122, 2003.

Shi, D., Xu, Y., and Morel, F. M. M.: Effects of the $\mathrm{pH} / \mathrm{pCO}_{2}$ control method on medium chemistry and phytoplankton growth, Biogeosciences, 6, 1199-1207, 2009, http://www.biogeosciences.net/6/1199/2009/.

Six, K. D. and MaierReimer, E., Effects of plankton dynamics on seasonal carbon fluxes in an ocean general circulation model, Global Biogeochem. Cy., 10, 559-583, 1996.

Thingstad, T. F., Bellerby, R. G., Bratbak, G., Børsheim, K. Y., 
Egge, J. K., Heldal, M., Larsen, A., Neill, C., Nejstgaard, J., Norland, S., Sandaa, R. A., Skjoldal, E. F., Tanaka, T., Thyrhaug, R., and Töpper, B.: Counterintuitive carbon-to-nutrient coupling in an Arctic pelagic ecosystem, Nature, 455, 387-391, 2008.

Turley, C. M. and Mackie, P. J.: Biogeochemical significance of attached and free-living bacteria and the flux of particles in the NE Atlantic, Mar. Ecol. Prog. Ser., 115, 191-203, 1994.

Tyrrell, T., Schneider, B., Charalampopoulou, A., and Riebesell, U.: Coccolithophores and calcite saturation state in the Baltic and Black Seas, Biogeosciences, 5, 485-494, 2008, http://www.biogeosciences.net/5/485/2008/.

Wolf-Gladrow, D. A., Riebesell, U., Burkhardt, S., and Bijma, J.: Direct effects of $\mathrm{CO}_{2}$ concentration on growth and isotopic composition of marine plankton, Tellus B, 51, 461-476, 1999.

Wolf-Gladrow, D. A., Zeebe., R. E., Klaas, C., Koertzinger, A., and Dickson, A. G.: Total alkalinity: the explicit conservative expression and its application to biogeochemical processes, Mar. Chem., 106, 287-300, doi:10.1016/j.marchem.2007.01.006, 2007.
Young, J. R., Geisen, M., Cros, L., Kleijne, et al.: A guide to extant coccolithophore taxonomy, Journal of Nannoplankton Research, Special Issue 1, 125 pp., 2003.

Young, J. R. and Westbroek, P.: Genotypic variation in the coccolithophorid species Emiliania huxleyi, Mar. Micropaleontol., 18, 5-23, 1991.

Zeebe, R. E. and Wolf-Gladrow, D.: $\mathrm{CO}_{2}$ in seawater: Equilibrium, kinetics, isotopes, Elsevier Oceanographic Series 65, Elsevier, New York, 2001.

Zondervan, I., Zeebe, R. E., Rost, B., and Riebesell, U.: Decreasing Marine Biogenic Calcification: A Negative Feedback on Rising Atmospheric $p \mathrm{CO}_{2}$, Global Biogeochem. Cy., 15, 507-516, 2001.

Zondervan, I., Rost, B., and Riebesell, U.: Effect of $\mathrm{CO}_{2}$ concentration on the PIC/POC ratio in the coccolithophore Emiliania huxleyi grown under light-limiting conditions and different daylengths, J. Exp. Mar. Biol. Ecol., 272, 55-70 2002. 